\title{
İnsülin Direncine Etki Eden Besinler
}

\author{
Foods That Effect Insulin Resistance
}

\author{
Özlem Çetiner ${ }^{1}$, Neslişah Rakıcıoğlu ${ }^{2}$
}

Geliş tarihi/Received: 24.11.2017 • Kabul tarihi/Accepted: 09.07.2018

\section{ÖZET}

İnsülin direnci, başta diyabet ve metabolik sendrom olmak üzere birçok hastalığın oluşum sürecinde rol oynayabilen önemli bir aktördür. Fiziksel aktivite ve beslenme gibi değiştirilebilir yaşam koşulları ile insülin direnci oluşumunun önüne geçilebilmektedir. Bu derleme yazının amacı, insülin direnci oluşumu ve yönetimi sürecinde etkili olduğu düşünülen besinleri incelemek ve olası yararları üzerinde durmaktır. Bu bağlamda, derleme kapsamında polifenol içeriği yüksek besinler ile posadan zengin besinler değerlendirilmiştir. İnsülin direncine etki eden ve etki ettiği düşünülen pek çok besin olmasına karşılık, tartışmalı ve zıt çalışmalar mevcuttur. Bu nedenle tek bir besin üzerinde yoğunlaşmak yerine diyetteki besin çeşitliliğini arttırıp, sözü geçen besinlerin diyete uygun miktarlarda eklenmesi daha yararlı bir yaklaşım olacaktır.

Anahtar kelimeler: İnsülin direnci, polifenollerden zengin besinler, posa

\begin{abstract}
Insulin resistance is an important agent that can play a role in the onset of many diseases, especially diabetes and metabolic syndrome. Insulin resistance can be avoided with changeable living conditions such as physical activity and nutrition. The aim of this review is to examine the foods that are thought to be effective in the process of insulin resistance pathogenesis and management, and to focus on their possible benefits. In this context, polyphenol rich foods and fiber rich foods have been evaluated in this review. Although there are many nutrients that affect insulin resistance, there are controversial and contrary studies. For this reason, instead of concentrating on a single food, it would be more beneficial to increase the food diversity in diet and to add mentioned nutrients in to diet at appropriate doses.
\end{abstract}

Keywords: Insulin resistance, polyphenol rich foods, fiber

\section{GİRiş}

İnsülin direnci tanımı genel olarak, normal kan insülin düzeylerine rağmen hedef dokuların insülin yanitının azalmasıyla karakterize olan durumu ifade etmek için kullanılır. Başta tip 2 diyabet olmak üzere obezite, dislipidemi, hipertansiyon patogenezinde insülin direnci önemli rol oynamaktadır. 2017 yılında Türkiye’nin 7 farklı bölgesinde yaşayan 3331 kişi

1. Atılım Üniversitesi, Sağlık Bilimleri Fakültesi, Beslenme ve Diyetetik Bölümü, Ankara, Türkiye

(D) https://orcid.org/0000-0001-9872-416X üzerinde yapılan bir çalışmaya göre insülin direnci prevalansı, \%26.2 bulunmuştur (1). Değiştirilebilir yaşam koşullarının, özellikle diyet etmenlerinin artan insülin direnci ve tip 2 diyabet prevalansını azaltmaya yönelik etkileri günümüzde pek çok araştırmaya konu olmaktadır (2-9).

2. İletişim/Correspondence: Hacettepe Üniversitesi, Sağlık Bilimleri Fakültesi, Beslenme ve Diyetetik Bölümü, Ankara, Türkiye

E-posta: neslisah@hacettepe.edu.tr • 마 https://orcid.org/0000-0001-8763-7407 
$\mathrm{Bu}$ derlemenin amacı, insülin direncine etki ettiği düşünülen besinlerin, glisemik kontrol üzerine olası etkilerini değerlendirmek, polifenollerden ve posadan zengin besinlerin insülin direncine olan etkisinde olası etki mekanizmalarının incelenmesidir.

\section{Polifenoller}

Epidemiyolojik çalışmalar polifenoller ve polifenol içeriği yüksek besinlerin glisemik kontrol ve tip 2 diyabet gelişiminin önlenmesinde yararlı etkileri olabileceği üzerinde durmaktadır $(10,11)$. Ín vitro çalışmalara göre polifenoller, hipoglisemik etkilerini 6 farklı mekanizma üzerinden gerçekleştirebilmektedir (12-16). Bu mekanizmalar, karbonhidrat emilimi ve sindirimi, dokulara glukoz alımı, pankreatik $\beta$ hücre işlevi, karaciğer glukoz homeostazı, inflamasyon ve bağırsak mikrobiyotası üzerinedir.

Polifenoller, emilim ve sindirim üzerine etkilerini, karbonhidrat sindirimde görevli temel enzimleri (a-amilaz ve a-glikosidaz) baskılayarak gösterebilirler. Bunun yanı sira flavonoidler ve fenolik asitler, SGLT1 aracılı glukoz taşınımını baskılayarak kana geçen glukoz miktarınıazaltırken, kolona geçen karbonhidrat miktarının arttırılmasına katkı sağlayabilmektedir (12). Kana geçen glukoz miktarının azalması, insülin salınımını azaltarak dokuları, hiperinsülineminin yarattığı hasara karşı korumaktadır.

İskelet kas hücrelerine glukoz alımı yine polifenoller aracılığıyla indüklenebilir. Epikateşin, epigallokateşin3-O-gallat (EGCG), kırmızı üzüm prosiyanidinleri, acı kavun, yaban mersini, tesbih çiçeği kökü ve siyah soya fasulyesinde bulunan polifenollerin, hayvanlarda GLUT4 bağımlı glukoz alımını uyararak dokulara glukoz alımını arttırdığı gösterilmiştir (12). Emilerek dokulara taşınan polifenoller ayrıca pankreatik $\beta$ hücrelerinin uyarılmasında da etkili olabilmektedir. EGCG ve karabuğday flavanoidlerinin rutin kullanımının, metformine benzer şekilde $\beta$-hücrelerde Adenozin monofosfat-aktive protein kinaz (AMPK) sinyalizasyonunu ve ATP düzeylerini arttırak insülin stimülasyonuna katkı sağladığı gösterilmiştir (13).
Polifenollerin adipositler ve hepatositler üzerine etkileri incelendiğinde ise özellikle yeşil çay polifenollerinden EGCG'ın glikoneonegez ve yağ asidi sentezini baskılarken, glikoliz ve glukoz transportunu uyardığı görülmüştür. Diyabetik farelerde yapılan bir çalışmada, EGCG'ın etkisi plasebo grubu ile karşılaştırılmış ve EGCG desteği alan farelerde plasebo alan kontrol grubuna göre kan glukoz düzeyi daha düşük bulunmuştur (14). Ayrıca polifenoller, pankreas, karaciğer ve diğer dokuları inflamatuvar hasardan koruyarak da insülin direnci gelişimini önleyebilmektedir. Yapılan bir çalışmada üzüm çekirdeği prosiyanidinlerinin yağdan zengin diyetle beslenen farelerde $C$ reaktif protein (CRP), IL-6, TNF- $a$ proinflamatuvar moleküllerin üretimini baskılarken, adiponektin salınımını arttırdığı gözlenmiştir (15).

Dokular üzerindeki olumlu etkilerine karşıllk, polifenollerin emilimi oldukça düşüktür. Diyetle alınan polifenollerin yaklaşık \%90-95'i emilmeden kolona geçer. Kolona geçen diyet polifenollerinin, Bifidobacteria ve diğer yararlı bakteri popülasyonunu arttırdığı gösterilmiştir (16). Bifidobacteria'dan zengin bir mikrobiyotanın, endotoksemiyi ve inflamatuvar sitokinleri azaltarak, glukoz toleransını geliştirerek tip 2 diyabete karşı koruyucu olabileceği belirtilmektedir (17-20).

\section{Polifenol İçeriği Zengin Besinler}

Çay ve Kahve: Çay, dünya çapında sudan sonra en çok tüketilen ikinci içecektir. Yeşil çay daha çok kateşinlerden zengin iken, siyah çay teaflavinlerden zengindir. Etken maddeleri farklı olmasına rağmen, siyah çay ve yeşil çayın hastalıklara karşı korumada benzer etkiler gösterdiği belirtilmektedir (21).

Yirmi iki randomize kontrol deneyin değerlendirildiği bir meta analiz çalışmasında, yeşil çay kateşinlerinin açlık glukoz düzeylerini düşürdüğü ancak, insülin, HbA1c ve HOMA-IR üzerine bir etkisinin olmadığı sonucuna ulaşılmıştır. Kan glukoz düzeylerini düşürücü etki, 12 hafta ve üzerindeki izlem çalışmalarında gözlenmiştir (22). Bu durum, yeşil çayın glisemik kontrol üzerine etkisinin uzun 
dönem tüketimlerde ortaya çıktığı görüşünü desteklemektedir. Siyah çay polifenollerinin tip 2 diyabet oluşum mekanizması üzerine etkisinin incelendiği bir çalışmada, siyah çay ekstraktı veya ezmesinin a-glikosidaz ve az miktarda a-amilaz aktivitesini baskllayarak postprandiyal hiperglisemi oluşumunda koruyucu olabileceği sonucuna varılmıştır (23). Yirmi dört sağlıklı ve pre-diyabetik bireyin katıldığı bir çalışmada, bireylerin sükroz solüsyonu tüketimini izleyen kan glukoz düzeyleri her 30 dakikada bir ölçülerek değerlendirilmiştir. Randomize olarak gruplara ayrılan bireylere sükroz solüsyonunun içinde düşük doz siyah çay polifenolleri, yüksek doz çay polifenolleri veya plasebo verilmiştir. Yüksek doz polifenol içeren sükroz solüsyonu tüketen grupta kan glukoz düzeyleri diğer gruba kıyasla anlamlı şekilde düşük bulunmuştur (24).

Global olarak çay ile benzer şekilde kahve de sıkça tüketilen bir diğer içecektir. Yapısındaki fenolik asit içeriğinin (klorojenik asitin), tip 2 diyabet patogenezinde rolünün olabileceği düşünülmektedir. Kahve içme alışkanlığı olan 18 tip 2 diyabetli bireyde, tek doz espressonun, oral glukoz tolerans testi (OGTT) boyunca, glukoz toleransı ve insülin duyarlılığına etkisinin incelendiği bir çalışmada, kahve, kan şekeri eğrisinin altında kalan alanda (AUC) anlamlı bir değişim yaratmamıştır (25). Kahvedeki klorojenik asidin gastrointestinal hormon salınımı ve glukoz alımı üzerine etkisinin incelendiği bir diğer çalışmada, klorojenik asidin sağlıklı bireylerde glisemi ve insülinemi üzerine bir etkisinin olmadığı, ancak gastrik inhibitör polipeptit (GIP) salınımını azalttığı ve GLP-1 salınımını arttırdığı görülmüştür. Kahve tüketen bireylerde kontrol grubuna göre intestinal emilim hızının daha yavaş olduğu gözlenmiştir (2). Bu sonuçlar, kahvenin emilim hızını ve gastrik boşalma hızını yavaşlatarak, glukoz homeostazı üzerinde etkili olabileceği görüşünü desteklemektedir.

Çikolata ve Kakao: Kakao, çikolata üretiminde kullanılan temel madde olup, yüksek düzeylerde polifenol içeriğine sahiptir. Kakao içerisindeki toplam polifenol miktarı, tohumun kuru ağırlığının \%6-8’i kadardır. Bitter (siyah) çikolatanın polifenol içeriği, sütlü çikolatanın yaklaşık 2.5 katı kadardır (26).

Kırk iki randomize kontrol deneyin sonuçlarının değerlendirildiği bir meta analiz çalışmasında, kısa dönem ( $\leq 18$ hafta) çikolata/kakao alımının kan şekeri ve insülin üzerine etkisi gözlenmiştir. Kakaonun, açlık insülin düzeyleri ve glukoz tüketimi sonrası insülin salınımı azalttığı, insülin direncini olumlu yönde etkilediği görülmüştür (27). Bitter çikolata (500 mg polifenol/100 g) ile beyaz çikolatanın ( $\sim 0 \mathrm{mg} / 90$ g) etkisinin karşılaştırıldığı bir başka çalışmada, 15 gün boyunca $100 \mathrm{~g}$ bitter çikolata tüketiminin, $90 \mathrm{~g}$ beyaz çikolata tüketimine kıyasla sağlıklı bireylerde kan basıncını ve insülin direnci homeostatik model değerlendirme indeksini (HOMA - IR) düşürdüğü, insülin duyarlılığı kontrol indeksi (QUICKI) arttırdığg görülmüştür (3). Diyabetik hipertansif hastalarda 8 hafta boyunca günde $25 \mathrm{~g}$ bitter çikolatanın veya $25 \mathrm{~g}$ beyaz çikolata tüketiminin kıyaslandığı bir çalışmada ise açlık glukoz ve insülin değerleri ile HbA1c düzeylerinin, polifenol içeriği ile değişim göstermediği sonucuna ulaşılmıştır (28).

Tarçın: Tarçın yapısında kateşin, prosiyanidin, sinamtannin trans-sinnamik asit ve flavonları içeren bir baharattır (12). Glisemik kontrol üzerine rolü olduğu düşünülen en popüler baharatlardan biri olan tarçın ile ilgili yapılmış çok sayıda çalışma bulunmaktadır (29-32).

Çin'de anti diyabetik kullanan 66 Tip 2 diyabet hastası üzerinde yapılan bir randomize kontrol çalışmasında, 90 gün boyunca günde $360 \mathrm{mg}$ ve $120 \mathrm{mg}$ tarçın ekstraktı alan bireyler ile plasebo alan bireylerin glisemik kontrolleri kıyaslanmıştır. HbA1c düzeyleri ve açlık kan glukoz değerlerinin tarçın ekstraktı alan gruplarda anlamlı şekilde düştüğü, ancak plasebo grubunda herhangi bir değişim olmadiğ gözlenmiştir (29). Yirmi iki bozulmuş glukoz toleransı olan hastanın 12 hafta boyunca incelendiği bir diğer çalışmada ise günde $500 \mathrm{mg}$ tarçın ekstraktı alımının oksidatif stres belirteçlerini düşürdüğü gözlenmiştir. Bu çalışmada ayrıca Malonaldehit (MDA) düzeyleri ile plazma glukozu arasında pozitif yönde bir korelasyon olduğu belirtilmiştir (30). Yirmi beş postmenapozal 
tip 2 diyabet hastasının 6 hafta değerlendirildiği bir randomize kontrol çalışmasında ise $1.5 \mathrm{~g} /$ gün tarçın alımının insülin duyarlılığı ve oral glukoz toleransını geliştirmediği sonucuna varılmıştır (31). Benzer şekilde tip 2 diyabetli 60 bireyin 12 hafta boyunca değerlendirildiği başka bir çalışmada 1 g/gün tarçın tüketiminin, kan şekeri ve insülin duyarlılığı üzerine bir etkisi olmadığı görülmüştür (32). Tarçın tüketiminin insülin direnci üzerine etkileri tartışmalı olduğundan, prediyabetik bireyler ve diyabetik bireyler için kanıta dayalı tüketim önerileri mevcut değildir.

Üzüm polifenolleri: Koyu renkli meyveler arasında zengin polifenol içeriğiyle dikkat çeken bir diğer besin de üzümdür. Proantosiyanidin, antosiyanin, flavonol ve flavanoller ile resveratrol, üzüm ve üzüm ürünlerinin yapısında saptanmış, yüksek biyolojik aktiviteye sahip olan polifenollerdir (33).

Tip 2 diyabet hastası 32 birey üzerinde yapılan bir randomize kontrol çalışmasında 4 hafta boyunca $600 \mathrm{mg} / g u ̈ n$ üzüm çekirdeği ekstraktı tüketiminin, fruktozamin düzeyleri, glutatyon, CRP ve total kolesterol düzeyleri üzerine olumlu etkileri olduğu ancak, HOMA-IR indeksi üzerine bir etkisinin olmadiğı gözlenmiştir (34). Başka bir çalışmada üzüm polifenolleri, tip 2 diyabet hastalarının birinci dereceden akrabalarında fruktoz kaynaklı oksidatif stres ve insülin direnci üzerine olumlu etkiler göstermiştir. Sekiz hafta boyunca 38 birey 2 g/gün üzüm polifenollerini veya plasebo tüketmiştir. Son 6 günde yağsız vücut kütlesi başına 3 g fruktoz yüklemesi yapılarak insülin duyarlılığı, oksidatif stres belirteçleri ve mitokondriyal solunumun iki grup arasındaki farkı değerlendirilmiştir. Plasebo grubunun hepatik insülin duyarlılığı \%20 azalmış, glukoz infüzyon hızı \%11 artış göstermiştir. Polifenol grubunda ise bu etkiler gözlenmemiştir. Ayrıca polifenol desteği, fruktoz kaynaklı oksidatif stres belirteçlerine karşı koruyucu etki göstermiştir (4). Üzüm üzerine yapılan çalışmalar daha çok üzüm polifenolleri üzerine yoğunlaşmış olup, salt üzüm tüketimini destekleyici çalışmalar bulunmamaktadır.
Kırmızı şarap: Üzüm polifenolleri şarap üretimi sırasında değişime uğramaktadır. Şarabın yapısında bulunan temel polifenoller, flavan-3-oller, flavan-3,4dioller ve antosiyaninlerdir. Bunun yanında, şarap, biyolojik olarak aktif bir bileşen olan resveratrol bileşenini de üzüme kıyasla yüksek oranda içermektedir. Beyaz şaraba (0.2 mg/L) kıyasla kırmızı şarap (5.8 mg/L) daha yüksek miktarda resveratrol içerir (12).

İki yüz yirmi dört tip 2 diyabet hastasının değerlendirildiği 2 ylllı randomize kontrollü bir çalışmada, günlük $150 \mathrm{~mL}$ mineralli su, beyaz şarap veya kırmızı şarap tüketiminin lipit profili ve glisemik kontrol üzerine etkisi değerlendirilmiştir. Şarap tüketen gruplarda lipit profili mineralli su grubuna göre gelişim göstermiş olsa da, yalnızca beyaz şarap grubunda açlık glukoz düzeyleri ve HOMA-IR indeksi düşüş göstermiştir (35). Beşi insülin tedavisi alan 15 erkek diyabet hastasının değerlendirildiği başka bir çalışmada, kırmızı şarap tüketiminin kısa dönem etkileri incelenmiştir. Öğün ile birlikte 2 bardak su veya kırmızı şarabın yarattığı insülin gereksinmesi yapay pankreas sistemi Biostator ile, glukoz toleransı ise postprandiyal glukoz düzeyleri ile ölçülmüştür. İnsülin kullanan hastalarda insülin gereksinmesi açısından şarap ve su tüketimi arasında anlamlı bir fark olmazken, insülin kullanmayanlarda öğünle beraber şarap tüketimi, glukozun tepe noktaya ulaşma süresini uzatmıştır (36). Kırmızı şarabın glisemik kontrol üzerine olumlu etkileri olabileceği değerlendirilse de Amerikan Diyabet Derneği (ADA), diyabet riski taşıyan ve diyabetli bireylerde alkol tüketiminin desteklenmemesi gerektiğini vurgulamaktadır (37).

Diğer kırmızı meyveler: Kırmızı meyveler (çilek, böğürtlen, yaban mersini, Frenk üzümü) fitokimyasal içeriği bakımından zengin bir meyve grubudur. Özellikle flavonoidler, stilbenoidler, fenolik asitler ve lignanlardan oldukça zengin olan bu meyvelerin insülin direnci üzerine rolü olabileceği düşünülmektedir (38). Ín vitro ortamda çilek ve böğürtlenin tannin içerikleri nedeniyle a-amilazın, yaban mersini ve Frenk üzümünün antosiyanin 
içerikleri nedeniyle a-glikosidazın iyi bir inhibitörü olduğu gösterilmiştir (39).

Sağlıklı bireyler üzerinde yapılan bir randomize kontrol çalışmasında $150 \mathrm{~g}$ meyve püresi ve plasebo tüketiminin ardından 3 saat boyunca kan glukoz düzeyleri ölçülmüştür. Yüz elli gramlık meyve püresi eş miktarlarda yaban mersini, Frenk üzümü, kızılcık ve çilek ile $35 \mathrm{~g}$ sükroz içerirken, plasebo benzer glisemik yanıta sahip $250 \mathrm{~mL}$ su, $35 \mathrm{~g}$ sükroz, $4.5 \mathrm{~g}$ glukoz ve $5.1 \mathrm{~g}$ fruktoz içermektedir. Kırmızı meyve püresi plaseboya göre kan glukoz düzeylerini 15 ve 30 . dakikalarda daha az yükseltirken 3. saat sonundaki glukoz yanıtları benzer bulunmuştur (40). Polifenol içeriklerinin yanı sıra posadan da zengin kırmızı meyveler, kan glukoz düzeylerinin tepe noktasına ulaşmas süresinin gecikmesine ve gastrik boşalmanın yavaşlamasına yardımcı olarak insülin direncinin kontrolüne katkı sağlayabilir.

Keten tohumu: Birçok bitki, yapısında az miktarda lignan adı verilen fitobesin ögesini içerir. Lignanlar posaya bağlı polifenoller olup, hem posanın olumlu etkilerini hem de polifenollerin antioksidan etkilerini bir arada gösterebilen bileşenlerdir. Keten tohumu insan beslenmesinde lignan için en iyi kaynaktır ve total polifenol içeriği oldukça yüksektir.

Obez veya fazla kilolu prediyabetik bireylerin katılımıyla gerçekleştirilen çapraz bir çalışmada 12'şer haftalık izlemler ile 0, 13, 26 g/gün keten tohumu tüketiminin glisemik kontrol üzerine etkisi değerlendirilmiştir. Diyetin bir parçası olarak keten tohumu tüketiminin glukoz ve insülin düzeylerini düşürdüğü, insülin duyarlılığını pozitif yönde geliştirdiği gözlenmiştir (5). Yirmi dokuz tip 2 diyabet hastası bireyin bir ay boyunca değerlendirildiği başka bir randomize kontrol çalışmasında ise $10 \mathrm{~g} /$ gün keten tohumu tozunun diyete eklenmesinin açlık glukoz düzeylerini \%19.7, glikolize hemoglobin düzeylerini \%15.6 oranında düşürdüğü görülmüştür (41). Keten tohumunun bu etkiyi, karaciğerde glikoneogenezin hız sinırlayıcı enzimini kodlayan fosfoenolpiruvat karboksikinaz (PEPCK) gen ekspresyonunu azaltarak gerçekleştirdiği düşünülmektedir. Keten tohumunun rutinde tüketimini öneren kanıta dayalı veriler olmasa da insülin direnci üzerine olası olumlu etkileri, düşük glisemik indeksi ve zengin n-3 yağ asidi içeriği nedeniyle diyabetik ve prediyabetik bireylerin diyetlerine eklenmesi yararlı olabilir.

Zerdeçal: Zerdeçal, zencefilgiller familyasından sarıçiçekli, büyük yapraklı, çok ylllık otsu bir bitki cinsidir. Hint safranı olarak da bilinir. Yapılan bir çalışmada zerdeçal içinde bulunan aktif bir bileşen olan turmeriğin, metformine kıyasla dokulara glukoz alımını arttırmada 500 ila 100.000 kat daha etkili olduğu sonucuna varılmıştır (42).

Zerdeçalın insülin direnci üzerine olumlu etkileri farklı hayvan çalışmalarında gösterilmiştir. Ratlarda yapılan bir çalışmada fruktoz ile indüklenen insülin direncinde, 15, 30, $60 \mathrm{mg} / \mathrm{kg}$ zerdeçal tüketiminin insülin reseptör aktivitesini arttırdığı sonucuna ulaşılmıştır (43). Zerdeçalın bu etkiyi, insülin reseptörlerinin deaktivasyonundan sorumlu, protein tirozin fosfataz 1B (PTP1B) ekspresyonunu baskılayarak gösterdiği ifade edilmiştir. Aynı çalışmada fruktozdan yüksek diyete 4 hafta boyunca 15-60 mg/gün zerdeçal eklemesinin insülin reseptör sayısını arttırdığı, IRS 1 fosforilasyonunu arttırarak, insülinin metabolik ve mitojenik yolaklarının aktivitesini uyardığı görülmüştür (43). Başka bir hayvan çalışmasında diyete zerdeçal eklenmesi, glikokinaz ve AMPK aktivitesini uyararak glikolitik faaliyetleri arttırırken, glukoz-6-fosfataz ve PEPCK aktivitesini baskllayarak glikoneonegezi azaltmış, böylelikle kan glukoz düzeylerini azaltmıştır (44). Prediyabetik bireyler üzerinde yapılan bir randomize kontrol çalışmasında, $1.5 \mathrm{~g} /$ gün zerdeçal ekstraktı kullanımının diyabet gelişimini önleyebileceği sonucuna varılmıştır. Çalışmada, plasebo grubundan 19 birey diyabet tanısı alırken, kontrol grubudan hiç kimse diyabet tanısı almamıştır. Üç aylık zerdeçal alımından sonra zerdeçal grubunda açlık kan şekeri, posprandiyal glukoz ve HbA1c düzeylerinin anlamlı şekilde azalmıştır. Dokuz ay sonunda ise vücut ağırlığı, bel çevresi, HOMA-IR ve C peptit düzeylerinin azalma gösterdiği görülmüştür (6). Literatürde zerdaçalın glikolitik yolaklar üzerinde olumlu yönde etkileri 
olabileceği görüşünü desteklese de, rutin kullanımını destekleyen kanıta dayalı öneriler mevcut değildir.

Zencefil: Zencefil bitkisi, 2500 yıldan fazla süredir Çin'de birçok hastalığın tedavisinde kullanılan ve sıklıkla baharat olarak tüketilen bir besindir. Zencefilin diyabet oluşumuna etkisi yine birkaç olası metabolik yolak ile açıklanmaktadır. Zencefil içerisindeki aktif bileşen olan gingerol, inflamasyona neden olan prostoglandin üretimini baskılayarak, diyabet gibi inflamatuvar temelli hastalıklara karşı koruyucu görev yapar. Ayrıca hayvan çalışmalarında zencefilin hepatik fosforilasyonu ve glikoneogenezi baskıladığı gözlenmiştir (45).

Tip 2 diyabetli 88 hastanın katılımıyla gerçekleşen bir randomize kontrollü bir çalışmada 8 hafta boyunca günde $3 \mathrm{~g}$ zencefil kapsülü tüketiminin açlık glukoz düzeylerini \%10.5 düşürdüğü, HbA1c düzeylerindeki düşüşün açlık kan glukoz düzeylerine benzer olduğu gözlenmiştir (46). Diyabetli bireylerdeki olumlu sonuçlara rağmen, sağlıklı bireylerde ve prediyabetiklerde zencefilin etkisi yaygin olarak araştırılmamıştır.

\section{Diyet Posası - İnsülin Direnci}

Birçok klinik ve epidemiyolojik çalışmada, diyet posası alımının arttırılmasının, insülin direncinin gelişimi ve tip 2 diyabet oluşumunun önlenmesinde önemli bir aktör olabileceği belirtilmiştir. Çözünebilir diyet posası, hem diyabetik bireylerde hem de sağlıklı bireylerde postprandiyal glukoz düzeylerini düşürerek insülin duyarlılığını arttırabilir. Ratlarda yapılan bir çalışmada fisilyum desteğinin iskelet kas hücrelerinde GLUT4 düzeylerini arttırarak, insülin direncine karşı koruyucu olabileceği bildirilmiştir (47). GLUT4 düzeylerindeki artışın, kolonik fermentasyon sonucu oluşan kısa zincirli yağ asitlerince uyarılan PPARy aktivitesi ile indüklendiği düşünülmektedir. Çözünür posa (özellikle oligosakkaritler) ayrıca, bağırsaklardan salınan inkretin hormonları (GLP1 ve GIP) uyarak pankreastan insülin salgısını uyarabilmektedir (48). Çözünmez posa da benzer şekilde insülin duyarlılığı üzerine pozitif etkilere sahiptir. Yapılan bazı çalışmalarda özellikle tip 2 diyabet gelişimini önlemede tam tahılların, sebze ve meyvelere göre daha etkili olabileceği belirtilmiştir (49). Posanın çözünebilir ve çözünmez olmasından ziyade fermente edilebilir olması, glisemik kontrol açısından daha anlamlıdır. Fruktanlar, galaktanlar, polyoller, fruktoz ve galaktoz fermente edilebilen karbonhidratlardır. Kolonik fermentasyon sonucu oluşan kısa zincirli yağ asitleri (asetat, bütirat, propiyonat) adipoz dokudan serbest yağ asidi salınımını baskılayarak antilipidemik etki gösterebilir.

Kanda serbest yağ asidi yüksekliği kaslarda ve hepatositlerde insülin direncine neden olurken, serbest yağ asitlerinin dokularda oluşturduğu lipotoksisite beta hücre disfonksiyonu üzerinde de etkili olabilmektedir. Kısa zincirli yağ asitleri bu anlamda insülin direci oluşumuna karşı koruyucu etki gösterir (50). Kısa zincirli yağ asitlerinden bütiratın ayrıca antiinflamatuvar etkisi bulunmaktadır. Bütirat, NF-кB üzerine inhibitör etki göstererek sitokin kaynaklı beta hücre hasarını engeller ve insülin duyarlılığını arttırabilir (48). Yirmi tip 2 diyabet hastası üzerinde yapılan bir çalışmada, bireyler 15 hafta boyunca gözlenmiştir. İlk hafta diyabet diyeti ve sülfonilüre tedavisi, izleyen 6 hafta tedaviye ek olarak 14g/gün psyllium, son 4 hafta ise yine diyabet diyetine ek sülfonilüre tedavisi almışlardır. Kan glukoz eğrisinin altında kalan alanın, psyllium eklendiği dönemde anlamlı olarak daha düşük olduğu gözlenmiştir (7). Obez/kilolu sağlıklı bireylerin değerlendirildiği başka bir çalışmada 31.2 g çözünmez posa ile zenginleştirilmiş beyaz ekmek ile normal beyaz ekmek tüketiminin glisemi üzerine etkisi araştırılmıştır. Zenginleştirilmiş ekmek tüketiminin vücudun glukoz yararlanımını arttırdığı, insülin duyarlılığını geliştirdiği ve insülin aktivitesini \%12 kadar arttırdığı gözlenmiştir (8). Yine başka bir çalışmada kadınlara 2 ay boyunca $10 \mathrm{~g} / g u ̈ n$ inülin veya maltodekstrinin verilmesinin glisemi üzerine etkisi değerlendirilmiştir. İnülin tüketen grubun açlık kan glukoz düzeyleri, HbA1c ve MDA düzeyleri başlangıca göre anlamlı şekilde düşerken, total antioksidan kapasiteleri artış göstermiştir (9). 
Özetle, posadan zengin besinler, farklı mekanizmalar üzerinden kan şekeri ve glisemik kontrol üzerine olumlu etkiler gösterebilmektedir. Diyabetik hastaların diyetinde özellikle tam tahılların önemli bir yeri olmakla birlikte diyet posa miktarının kabul edilebilir sınırlar içinde arttırılması önerilmektedir.

\section{SONUÇ VE ÖNERILER}

İnsülin direncine etki eden ve etki ettiği düşünülen pek çok besin olmasına karşılık, elde edilen sonuçlar tartışmalıdır. Yukarıda özetlendiği üzere adı geçen besinlerin diyetin bir parçası haline getirilmesi ve uygun miktarlarda tüketimi ile diyete adaptasyonunun gerçekleştirilmesi, insülin direncinin kontrolünde bazı olumlu etkilere sahip olabilir. Ancak genel bir öneride bulunmak için kanıtlar yeterli değildir ve daha kapsamlı çalışmalara gerek vardır. Sağlıklı beslenmede, diğer besinlerin de kan şekerinin regülasyonunda olası etkilerinin olabileceği düşüncesinden hareketle, hem diyabet hem de diğer birçok kronik hastalığın önlemesi ve tedavisinde besin çeşitliliğinin sağlanması önem taşımaktadır.

Çıkar çatışması - Conflict of interest: Yazarlar çıkar çatışması olmadığını beyan ederler. - The authors declare that they have no conflict of interest.

\section{KAYNAKLAR}

1. Kaya A, Turan E, Uyar M, Bayram F, Turan Y. The prevalence of insulin resistance in the Turkish Population: A study conducted with 3331 participants. EJMO 2017;1(4):202-206.

2. Johnston KL, Clifford MN, Morgan LM. Coffee acutely modifies gastrointestinal hormone secretion and glucose tolerance in humans: glycemic effects of chlorogenic acid and caffeine. Am J Clin Nutr 2003;78(4):728-733.

3. Grassi D, Lippi C, Necozione S, Desideri G, Ferri C. Shortterm administration of dark chocolate is followed by a significant increase in insulin sensitivity and a decrease in blood pressure in healthy persons. Am J Clin Nutr 2005;81(3):611-614.

4. Hokayem M, Blond E, Vidal H, Lambert K, Meugnier E, Feillet-Coudray C, et al. Grape polyphenols prevent fructose-induced oxidative stress and insulin resistance in first-degree relatives of type 2 diabetic patients.
Diabetes Care 2013;36(6):1454-1461.

5. Hutchins AM, Brown BD, Cunnane SC, Domitrovich SG, Adams ER, Bobowiec CE. Daily flaxseed consumption improves glycemic control in obese men and women with pre-diabetes: a randomized study. Nutr Res 2013;33(5):367-375.

6. Chuengsamarn S, Rattanamongkolgul S, Luechapudiporn R, Phisalaphong C, Jirawatnotai S. Curcumin extract for prevention of type 2 diabetes. Diabetes Care 2012;35(11):2121-2127.

7. Sierra M, García J, Fernández N, Diez M, Calle A. Therapeutic effects of psyllium in type 2 diabetic patients. Eur J Clin Nutr 2002;56(9):830-842.

8. Weickert MO, Möhlig M, Schöfl C, Arafat AM, Otto B, Viehoff $\mathrm{H}, \mathrm{vd}$. Cereal fiber improves whole-body insulin sensitivity in overweight and obese women. Diabetes Care 2006;29(4):775-780.

9. Pourghassem Gargari B, Dehghan P, Aliasgharzadeh A, Asghari Jafar-abadi M. Effects of high performance inulin supplementation on glycemic control and antioxidant status in women with type 2 diabetes. Diabetes Metab J 2013;37(2):140.

10. Liu Y-J, Zhan J, Liu X-L, Wang Y, Ji J, He Q-Q. Dietary flavonoids intake and risk of type 2 diabetes: A metaanalysis of prospective cohort studies. Clin Nutr 2014;33(1):59-63.

11. van Dam RM, Willett WC, Manson JE, Hu FB. Coffee, caffeine, and risk of type 2 diabetes: a prospective cohort study in younger and middle-aged U.S. women. Diabetes Care 2006;29(2):398-403.

12. Kim YA, Keogh JB, Clifton PM. Polyphenols and glycemic control. Nutrients 2016;8(1):1-27.

13. Cai EP, Lin J-K. Epigallocatechin gallate (EGCG) and rutin suppress the glucotoxicity through activating IRS2 and AMPK signaling in rat pancreatic $\beta$ Cells. J Agric Food Chem 2009;57(20):9817-9827.

14. Wolfram S, Raederstorff D, Preller M, Wang Y, Teixeira SR, Riegger C, et al. Epigallocatechin gallate supplementation alleviates diabetes in rodents. J Nutr 2006;136(10):2512-2518.

15. Terra X, Montagut G, Bustos M, Llopiz N, Ardèvol A, Bladé C, et al. Grape-seed procyanidins prevent lowgrade inflammation by modulating cytokine expression in rats fed a high-fat diet. J Nutr Biochem 2009;20(3):210218.

16. Tzounis X, Rodriguez-Mateos A, Vulevic J, Gibson GR, Kwik-Uribe C, Spencer JP. Prebiotic evaluation of cocoa-derived flavanols in healthy humans by using a randomized, controlled, double-blind, crossover intervention study. Am J Clin Nutr 2011;93(1):62-72.

17. Le TKC, Hosaka T, Le TTT, Nguyen TG, Tran QB, Le $\mathrm{THH}$, et al. Oral administration of Bifidobacterium spp. 
improves insulin resistance, induces adiponectin, and prevents inflammatory adipokine expressions. Biomed Res 2014;35(5):303-310.

18. Tonucci LB, Olbrich Dos Santos KM, Licursi de Oliveira L, Rocha Ribeiro SM, Duarte Martino HS. Clinical application of probiotics in type 2 diabetes mellitus: A randomized, double-blind, placebo-controlled study. Clin Nutr 2017;36(1):85-92.

19. Zhang $\mathrm{Y}$, Zhang H. Microbiota associated with type 2 diabetes and its related complications. Food Sci Hum Wellness 2013;2(3-4):167-172.

20. Cani PD, Neyrinck AM, Fava F, Knauf C, Burcelin RG, Tuohy KM, et al. Selective increases of bifidobacteria in gut microflora improve high-fat-diet-induced diabetes in mice through a mechanism associated with endotoxaemia. Diabetologia 2007;50(11):2374-2383.

21. Leung LK, Su Y, Chen R, Zhang Z, Huang Y, Chen Z. Theaflavins in black tea and catechins in green tea are equally effective antioxidants. J Nutr 2001;131(9):22482251.

22. Zheng XX, Xu YL, Li SH, Hui R, Wu YJ, Huang XH. Effects of green tea catechins with or without caffeine on glycemic control in adults: a meta-analysis of randomized controlled trials. Am J Clin Nutr 2013;97(4):750-762.

23. Striegel L, Kang B, Pilkenton SJ, Rychlik M, Apostolidis E. Effect of black tea and black tea pomace polyphenols on a-glucosidase and a-amylase inhibition, relevant to type 2 diabetes prevention. Front Nutr 2015;2:3.

24. Butacnum A, Chongsuwat R, Bumrungpert A. Black tea consumption improves postprandial glycemic control in normal and pre-diabetic subjects: a randomized, double-blind, placebo-controlled crossover study. Asia Pac J Clin Nutr 2017;26(1):59-64.

25. Yamashita K, Yatsuya H, Muramatsu T, Toyoshima H, Murohara T, Tamakoshi K. Association of coffee consumption with serum adiponectin, leptin, inflammation and metabolic markers in Japanese workers: a cross-sectional study. Nutr Diabetes 2012;2(4):e33.

26. Çakır Y, Şanlıer N. The relationship between cardiovascular health and polyphenols found in Cocoa and Chocolate. Turkiye Klin J Heal Sci 2016;1(3):213-222.

27. Hooper L, Kay C, Abdelhamid A, Kroon PA, Cohn JS, Rimm EB, et al. Effects of chocolate, cocoa, and flavan3-ols on cardiovascular health: a systematic review and meta-analysis of randomized trials. Am J Clin Nutr 2012;95(3):740-751.

28. Rostami A, Khalili M, Haghighat N, Eghtesadi S, Shidfar F, Heidari I, et al. High-cocoa polyphenol-rich chocolate improves blood pressure in patients with diabetes and hypertension. ARYA Atheroscler 2015;11(1):21-29.

29. Lu T, Sheng H, Wu J, Cheng Y, Zhu J, Chen Y. Cinnamon extract improves fasting blood glucose and glycosylated hemoglobin level in Chinese patients with type 2 diabetes. Nutr Res 2012;32(6):408-412.

30. Roussel A-M, Hininger I, Benaraba R, Ziegenfuss TN, Anderson RA. Antioxidant effects of a cinnamon extract in people with impaired fasting glucose that are overweight or obese. J Am Coll Nutr 2009;28(1):16-21.

31. Vanschoonbeek K, Thomassen BJW, Senden JM, Wodzig W, van Loon LJC. Cinnamon supplementation does not improve glycemic control in postmenopausal type 2 diabetes patients. J Nutr 2006;136(4):977-980.

32. Suppapitiporn S, Kanpaksi N, Suppapitiporn S. The effect of cinnamon cassia powder in type 2 diabetes mellitus. J Med Assoc Thai 2006;89(3):200-205.

33. Xia EQ, Deng GF, Guo YJ, Li HB. Biological activities of polyphenols from grapes. Int J Mol Sci 2010;11(2):622646.

34. Kar P, Laight D, Rooprai HK, Shaw KM, Cummings M. Effects of grape seed extract in type 2 diabetic subjects at high cardiovascular risk: a double blind randomized placebo controlled trial examining metabolic markers, vascular tone, inflammation, oxidative stress and insulin sensitivity. Diabet Med 2009;26(5):526-531.

35. Gepner Y, Golan R, Harman-Boehm I, Henkin Y, Schwarzfuchs D, Shelef I, vd. Effects of initiating moderate alcohol intake on cardiometabolic risk in adults with type 2 diabetes a 2-year randomized, controlled trial. Ann Int Med 2015;163(8):569-579.

36. Gin H, Morlat P, Ragnaud JM, Aubertin J. Short-term effect of red wine (consumed during meals) on insulin requirement and glucose tolerance in diabetic patients. Diabetes Care 1992;15(4):546-548.

37. Franz MJ, Evert AB. American Diabetes Association guide to nutrition therapy for diabetes. 2012. p.19-69.

38. Seeram NP, Adams LS, Zhang Y, Lee R, Sand D, Scheuller HS, et al. Blackberry, black raspberry, blueberry, cranberry, red raspberry, and strawberry extracts inhibit growth and stimulate apoptosis of human cancer cells in vitro. J Agric Food Chem 2006;54(25):9329-9339.

39. McDougall GJ, Shpiro F, Dobson P, Smith P, Blake A, Stewart D. Different polyphenolic components of soft fruits inhibit a-amylase and a-glucosidase. J Agric Food Chem 2005;53(7):2760-2766.

40. Törrönen R, Sarkkinen E, Tapola N, Hautaniemi E, Kilpi K, Niskanen L. Berries modify the postprandial plasma glucose response to sucrose in healthy subjects. Br J Nutr 2010;103(8):1094-1097.

41. Mani UV, Mani I, Biswas M, Kumar SN. An openlabel study on the effect of flax seed powder (Linum usitatissimum) supplementation in the management of diabetes mellitus. J Diet Suppl 2011;8(3):257-265.

42. Kim T, Davis J, Zhang AJ, He X, Mathews ST. Curcumin 
activates AMPK and suppresses gluconeogenic gene expression in hepatoma cells. Biochem Biophys Res Commun 2009;388(2):377-382.

43. Li J-M, Li Y-C, Kong L-D, Hu Q-H. Curcumin inhibits hepatic protein-tyrosine phosphatase $1 \mathrm{~B}$ and prevents hypertriglyceridemia and hepatic steatosis in fructosefed rats. Hepatology 2010;51(5):1555-1566.

44. Kang C, Kim E. Synergistic effect of curcumin and insulin on muscle cell glucose metabolism. Food Chem Toxicol 2010;48(8-9):2366-2373.

45. Abdulrazaq NB, Cho MM, Win NN, Zaman R, Rahman MT. Beneficial effects of ginger (Zingiber officinale) on carbohydrate metabolism in streptozotocin-induced diabetic rats. Br J Nutr 2012;108(7):1194-1201.

46. Mozaffari-Khosravi H, Talaei B, Jalali B-A, Najarzadeh A, Mozayan MR. The effect of ginger powder supplementation on insulin resistance and glycemic indices in patients with type 2 diabetes: A randomized, double-blind, placebo-controlled trial. Complement Ther Med 2014;22(1):9-16.

47. Song YJ, Sawamura M, Ikeda K, Igawa S, Yamori Y. Soluble dietary fibre improves insulin sensitivity by increasing muscle GLUT-4 content in stroke-prone spontaneously hypertensive rats. Clin Exp Pharmacol Physiol 2000;27(1-2):41-45.

48. Galisteo M, Duarte J, Zarzuelo A. Effects of dietary fibers on disturbances clustered in the metabolic syndrome. J Nutr Biochem 2008;19(2):71-84.

49. Schulze MB, Schulz M, Heidemann C, Schienkiewitz A, Hoffmann K, Boeing H. Fiber and magnesium intake and incidence of type 2 diabetes. Arch Intern Med 2007;167(9):956.

50. Maki KC, Rains TM. Fiber and Insulin Sensitivity. In: Zimerang $\mathrm{MB}$, editor. Topics in the Prevention, Treatment and Complications of Type 2 Diabetes. Croatia: InTech; 2011. p. 177-90. 